O R I G I N A L

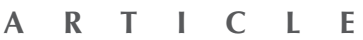

\title{
Percutaneous cementoplasty of osteolytic metastases induces immediate and long-lasting pain relief in oncological patients
}

\author{
OC Leung 梁安祥 \\ WL Poon 潘偉麟 \\ SF Nyaw 饒仕鋒 \\ SH Luk 陸秀霞
}

Key words

Bone neoplasms; Cementoplasty; Pain management

Hong Kong Med J 2013;19:317-22 DOI: $10.12809 / \mathrm{hkmj} 133743$

Tuen Mun Hospital, Tuen Mun, Hong Kong Department of Diagnostic Radiology OC Leung, MB, BS

SH Luk, MB, BS, FHKAM (Radiology) Department of Clinical Oncology SF Nyaw, MB, ChB

Department of Radiology and Imaging Queen Elizabeth Hospital, Jordan, Hong Kong

WL Poon, MB, BS, FHKAM (Radiology)

Correspondence to: Dr WL Poon Email: williamwlpoon@gmail.com
Objective To evaluate the clinical efficacy of percutaneous cementoplasty with respect to pain relief in patients with refractory painful bone metastases.

Design Case series.

Setting Regional hospital, Hong Kong.

Patients All oncological patients with painful bone metastases despite conventional treatment seen between October 2006 and May 2010 were recruited.

Interventions Cementoplasty with or without radiofrequency ablation.

Main outcome measures Pain score before and after the procedure.

Results In all, 12 patients with 13 lesions received cementoplasty. Two patients were excluded from the analysis because of inadequate documentation of pain score due to rapid disease progression. For the remaining 10 patients with 11 metastases, the primary sites were the lung $(n=3)$, renal cell carcinoma $(n=2)$, rectum $(n=2)$, pancreas $(n=1)$, multiple myeloma $(n=1)$, and soft tissue sarcoma $(n=1)$. The locations of the metastatic lesions were scapula $(n=1)$, thoracic vertebrae $(n=1)$, lumbar vertebrae $(n=3)$, and pelvic bones $(n=6)$. Eight lesions were treated by cementoplasty alone, whereas the other three associated with large soft tissue components had radiofrequency ablation followed by cementoplasty in a single setting. Immediate or near-immediate pain relief after treatment was achieved in $\mathbf{1 0}$ out of 11 lesions; the median pain score was 5 before treatment and decreased to 2 a week after treatment $(P=0.039)$. In all lesions for which the pain was successfully controlled in the first week, the palliation effect persisted at subsequent follow-ups. The median follow-up period for these patients was 16 weeks, and the longest pain-relieving effect was at least 9 months.

Conclusion In our experience, cementoplasty with or without radiofrequency ablation achieves satisfactory and long-lasting pain control in oncological patients with bone metastases. This is the first local study to describe the effect of cementoplasty for pain relief. Patients with painful bone metastases that are refractory to conventional treatments can benefit from cementoplasty, which should therefore be considered when conservative treatments fail.
New knowledge added by this study

This is the first local study to examine the effect of cementoplasty for pain relief.

Implications for clinical practice or policy

- Cementoplasty with or without radiofrequency ablation for pain relief should be considered whenever conservative treatments fail.

\section{Introduction}

Bone metastases are detected in 30 to $70 \%$ of oncological patients, ${ }^{1}$ and are more likely to be found if the disease is advanced. For patients with terminal disease and multiple sites of metastases, preserving quality of life is one of the main concerns. However, their 


\section{針對溶骨性轉移的經皮骨水泥成形術於癌症患者 引發的即時和持久鎮痛}

\begin{tabular}{|c|c|}
\hline 目的 & $\begin{array}{l}\text { 評估針對頑固性溶骨性轉移的經皮骨水泥成形術在鎮 } \\
\text { 痛方面的臨床果效。 }\end{array}$ \\
\hline 設計 & 病例系列。 \\
\hline 安排 & 香港一所醫院。 \\
\hline 患者 & $\begin{array}{l}\text { 2006年10月至2010年5月期間, 所有經常規治療但仍 } \\
\text { 患有骨轉移疼痛的癌症患者。 }\end{array}$ \\
\hline 干預 & 加入或不加入射頻消融的骨水泥成形術。 \\
\hline 主要結果測量 & 術前和術後的痛苦比分。 \\
\hline 結果 & 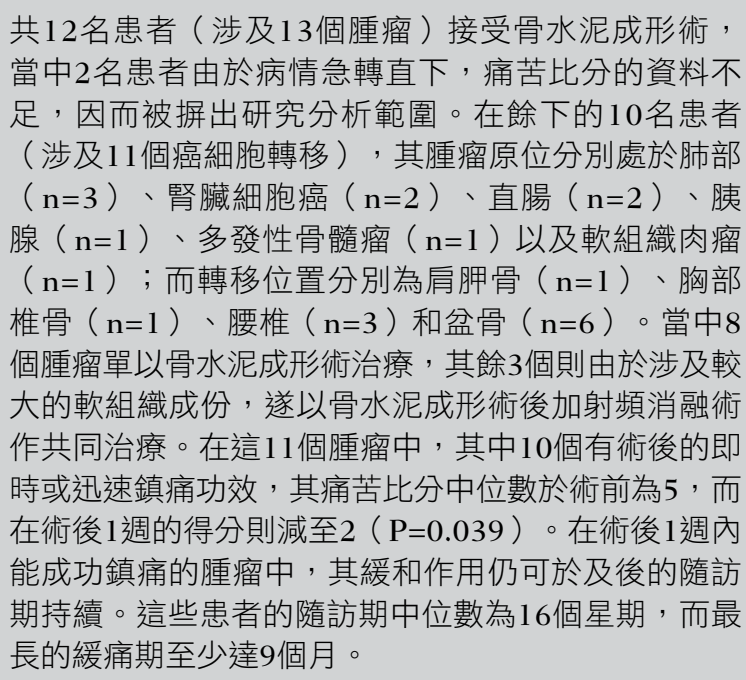 \\
\hline 結論 & $\begin{array}{l}\text { 根據我們的經驗, 無論是否加入射頻消融術, 骨水泥 } \\
\text { 成形術皆可令有骨轉移疼痛的癌症患者達到令人滿意 } \\
\text { 和持久的緩痛效果。這是本地首個檢視骨水泥成形術 } \\
\text { 緩痛效用的研究。對於常規治療效果不理想的骨轉移 } \\
\text { 疼痛患者, 骨水泥成形術可令他們受益。因此, 當保 } \\
\text { 守治療效果不理想時, 可考慮此療法。 }\end{array}$ \\
\hline
\end{tabular}




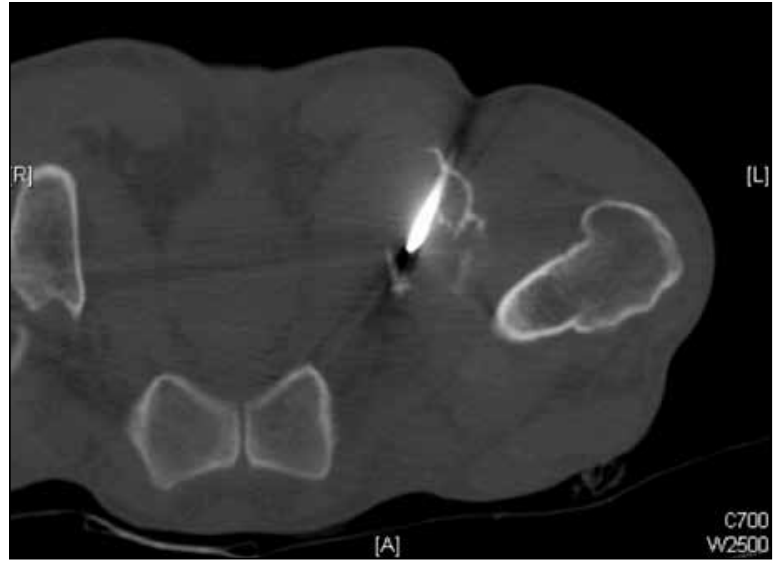

FIG 2. An axial computed tomographic (CT) image of the pelvis obtained during the procedure showing insertion of bone biopsy needle under CT guidance

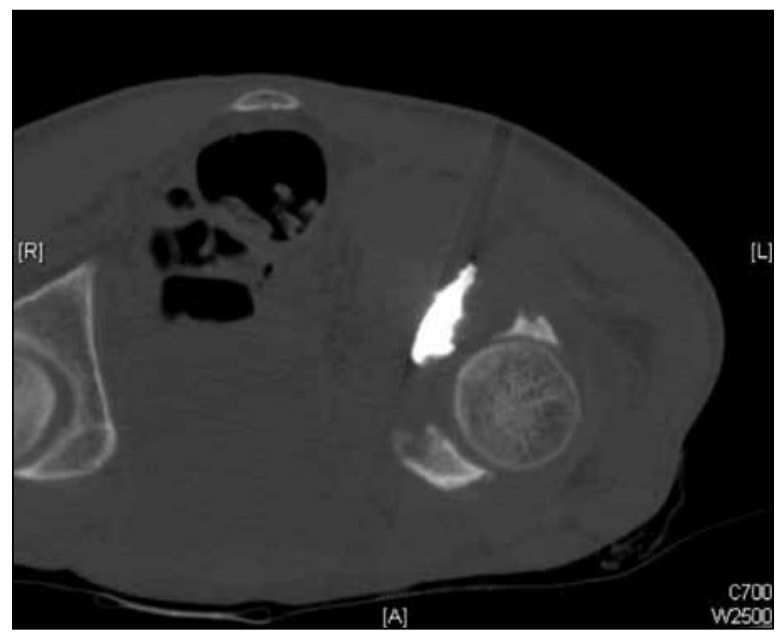

FIG 3. Post-treatment computed tomographic pelvis showing satisfactory cement injection into the metastatic lesion
As the sample size was small and the pain score was an ordinal variable, the two-tailed sign test was employed for statistical analysis. Statistical significance was set at the $5 \%$ level.

\section{Interventional techniques}

During cementoplasty with or without RFA, the location of the lytic bone lesion was first located by fluoroscopy or CT as shown in Figure 1. For lesions with significant soft tissue component, RFA was given before cementoplasty. For RFA, an ablation needle was first inserted into the bone lesion under image guidance; ablation was then performed according to the manufacturer's protocol. After ablation of the lesion, the ablation needle was removed and replaced by a bone biopsy needle, which was then inserted along the same tract (Fig 2). Bone cement was injected into the bone lesion under real-time fluoroscopic control until the whole lesion was filled with cement. For patients who did not receive RFA, the bone biopsy needle was introduced into the lesion directly under fluoroscopic or CT guidance, and cement injection was performed as described before. Post-treatment CT was performed to confirm the location, the amount of cement injection (Fig 3), and to look for extralesional cement leakage.

\section{Results}

In this study, the age of the patients ranged from 28 to 72 years. All 12 patients had intolerable pain despite conventional treatments; 10 of them also received radiotherapy for pain control weeks or months before the interventional procedure. These 12 patients had 13 lesions treated by cementoplasty; three of these lesions were treated by RFA before cementoplasty at the same setting, while the rest were

TABLE I. Summary of patient characteristics, type of primary malignancy, and site of painful metastases for the II procedures analysed in this study*

\begin{tabular}{lccllll}
\hline $\begin{array}{l}\text { Lesion } \\
\text { No. }\end{array}$ & Sex & $\begin{array}{c}\text { Age } \\
\text { (years) }\end{array}$ & Primary site & $\begin{array}{l}\text { Site of metastatic } \\
\text { lesion }\end{array}$ & Date & Procedure \\
\hline 1 & M & 69 & RCC & Acetabulum & October 2006 & RFA/cementoplasty \\
\hline $2^{\dagger}$ & M & 49 & Lung & Ischium & January 2009 & RFA/cementoplasty \\
\hline 3 & M & 72 & Rectum & Pubic ramus & May 2009 & Cementoplasty \\
\hline 4 & M & 62 & Multiple myeloma & Thoracic spine & September 2009 & Cementoplasty \\
\hline 5 & F & 59 & RCC & Lumbar spine & September 2009 & RFA/cementoplasty \\
\hline 6 & M & 28 & Sarcoma & Acetabulum & January 2010 & Cementoplasty \\
\hline 7 & M & 72 & Rectum & Acetabulum & February 2010 & Cementoplasty \\
\hline $8^{\dagger}$ & M & 49 & Lung & Lumbar spine & February 2010 & Cementoplasty \\
\hline 9 & F & 46 & Pancreas & Lumbar spine & February 2010 & Cementoplasty \\
\hline 10 & F & 64 & Lung & Pelvis & April 2010 & Cementoplasty \\
\hline 11 & M & 51 & Lung & Scapula & May 2010 & Cementoplasty \\
\hline
\end{tabular}

* RCC denotes renal cell carcinoma, and RFA radiofrequency ablation

+ Lesion No. 2 and 8 are of the same patient 
only treated by cementoplasty. Two patients were excluded from further study because of inadequate documentation of pain scores due to rapid disease progression. Among the remaining 10 patients with 11 metastases, the primary sites were lung $(n=3)$, renal cell carcinoma $(n=2)$, rectum $(n=2)$, pancreas $(n=1)$, multiple myeloma $(n=1)$, and soft tissue sarcoma $(n=1)$. The location of metastatic lesions were scapula $(n=1)$, thoracic vertebrae $(n=1)$, lumbar vertebrae $(n=3)$, and pelvic bones $(n=6)$ [Table 1]. In all, there were eight lesions treated by cementoplasty alone while three had both RFA and cementoplasty in a single setting. The latter three patients had large soft tissue components associated with the lytic lesions.

Immediate or near-immediate pain relief after treatment was observed for 10 lesions, with the median pain score of 5 before treatment and decreased to 2 a week later $(\mathrm{P}=0.039)$ [Table 2 and Fig 4]. In these 10 lesions for which the pain was successfully controlled in the first week, the palliation effect was noted to be lasting in subsequent follow-ups. The median followup period for these patients was 16 weeks, and the longest pain-relieving effect was at least 9 months. One patient who had a metastasis at L1 vertebra and received combined RFA and cementoplasty developed irreversible left lower limb paralysis after the treatment. Post-procedural magnetic resonance imaging and CT scans demonstrated no cement leakage into the epidural space, no evidence of cord compression, and the needle tract was shown to be totally transpedicular and had not entered the spinal canal.

TABLE 2. Pain scores of patients recorded before and after treatment until last follow-up or death*

\begin{tabular}{|c|c|c|c|c|c|c|c|c|c|c|c|c|c|c|c|}
\hline $\begin{array}{l}\text { Lesion } \\
\text { No. }\end{array}$ & Do & D1 & D2 & Wk 1 & Wk 2 & Wk 3 & M1 & M2 & M3 & M4 & M5 & M6 & M7 & M8 & M9 \\
\hline 1 & 6 & - & - & 1 & - & 2 & - & - & - & - & - & - & - & - & - \\
\hline 2 & 2 & 7 & 2 & - & - & - & 1 & - & 1 & - & 0 & - & 0 & - & 1 \\
\hline 3 & 8 & 3 & - & - & - & - & 4 & 2 & 2 & - & 0 & - & 0 & - & - \\
\hline 4 & 5 & 2 & 0 & 0 & 0 & 0 & 0 & 0 & 0 & 0 & - & - & - & - & - \\
\hline 5 & 7 & 4 & 4 & 4 & 4 & - & - & - & 4 & 4 & - & - & - & - & - \\
\hline 6 & 2 & 2 & 0 & 1 & 1 & 2 & 2 & - & - & - & 6 & & 0 & & \\
\hline 7 & - & 3 & 4 & 0 & 0 & 0 & 0 & 0 & 0 & 0 & - & - & - & - & - \\
\hline 8 & 2 & 3 & 4 & 4 & 3 & 0 & - & - & - & - & - & - & - & - & - \\
\hline 9 & 3 & 3 & 2 & - & - & - & - & - & - & - & - & - & - & - & - \\
\hline 10 & 5 & 5 & 3 & 3 & - & - & 3 & 3 & - & - & - & - & - & - & - \\
\hline 11 & 5 & - & 4 & 4 & 3 & - & - & - & - & - & - & - & - & - & - \\
\hline
\end{tabular}

* D denotes day, Wk week, and M month

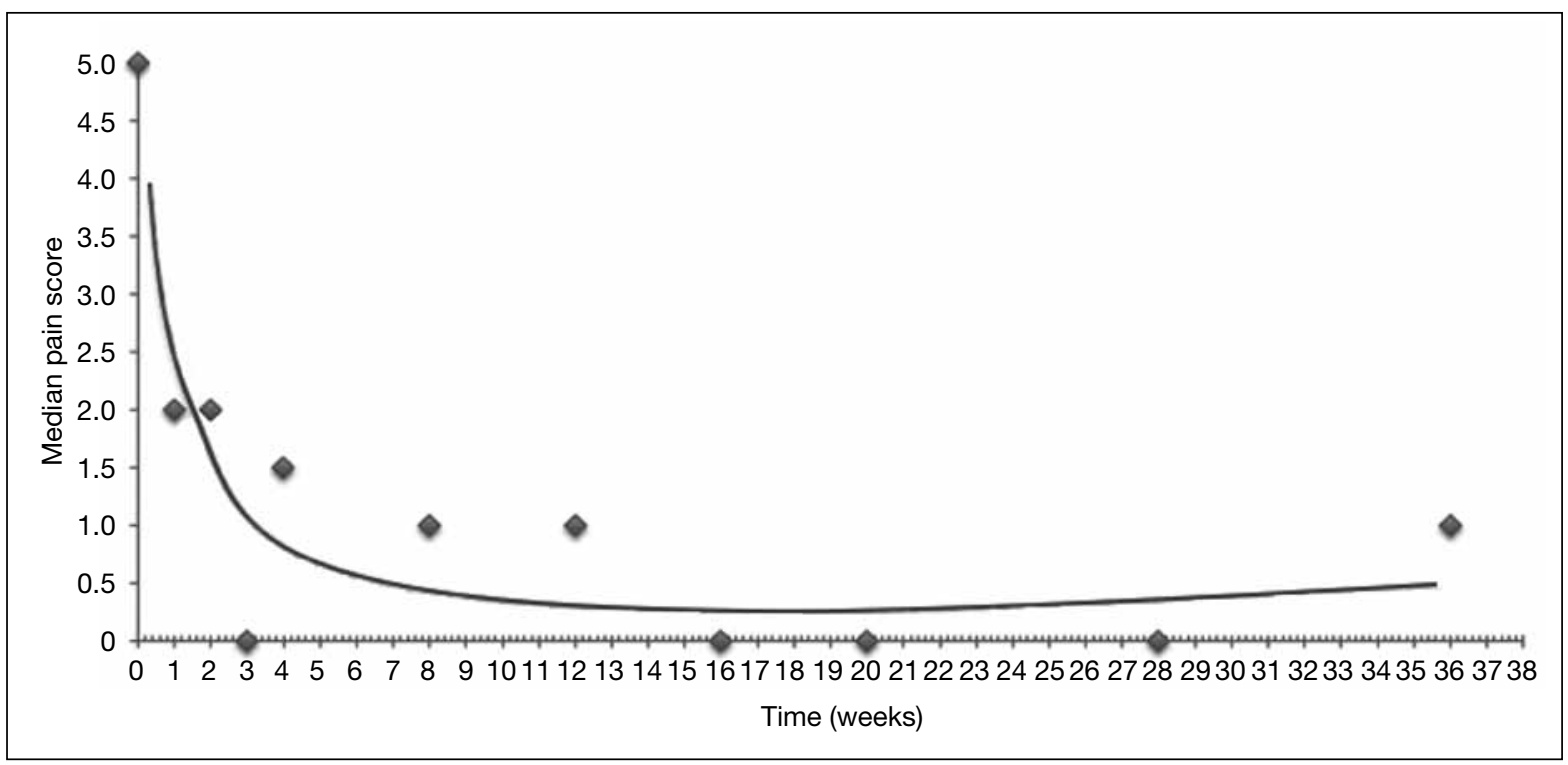

FIG 4. Median pain score of patients before and after treatment 


\section{Discussion}

The primary aim of this study was to evaluate the painrelieving effect of cementoplasty with or without RFA in bone metastases over time. Oncological patients with bone metastases could suffer from debilitating pain, especially in weight-bearing regions. Thus, pain control is one of the major steps in improving the quality of life in these terminal patients.

Analgesics, in form of the enteral or parenteral agents, and radiation therapy are traditional means of controlling pain related to bone metastases. In recent years, the development of percutaneous interventional radiological procedures, including cementoplasty, RFA, alcohol injection, cryotherapy and others ${ }^{4-7}$ provide alternative strategies for patients with bone metastases causing pain that cannot be adequately controlled by conventional methods.

Different studies have demonstrated improvement in pain and walking ability after percutaneous radiological interventions that have also been shown to be safe. ${ }^{7-14}$ However, their potential complications include local wound infection or inflammation, leakage of cement outside the bone into adjacent soft tissue or joint spaces, all of which could be prevented by delayed instillation of cement and close monitoring by fluoroscopy during the injection. In our study, one patient developed left lower limb paralysis after the procedure, which was attributed to thermal injury of the nerve roots during RFA. The complication was uncommon, even in patients with vertebral tumours associated with a posterior wall defect. ${ }^{15}$

Among all of the percutaneous interventional radiological procedures, cementoplasty and RFA have demonstrated more promising results in pain control, both of which can be used separately or together in the same setting (depending on the nature of the lesions). ${ }^{13,14}$ However, there is no large-scale study to evaluate whether combined treatment by cementoplasty and RFA is superior to cementoplasty alone. Whilst RFA can help debulking of the tumour mass, ${ }^{11,12}$ cementoplasty may help consolidate the damaged bone sufficiently to decrease the chance of pathological fracture. ${ }^{7-10}$ Thus, in theory, the combined use of RFA and cementoplasty could provide better palliative effects than either treatment alone.

In our study, most of the sites with painful metastases that received treatment were at weightbearing regions; the sites involved included the thoracic and lumbar spine, the pelvis, and the scapula. Regarding the 11 evaluated lesions, 10 enjoyed pain-relief effect within the first week and the median pain score decreased from 5 to 2 within this period $(\mathrm{P}=0.039)$. The pain scores were documented until the last follow-up or death of the patients. Looking at the changes of pain score over time, we demonstrated that in most of the patients, pain relief after cementoplasty with or without RFA was evident in the first 2 to 3 weeks after treatment. In addition, the effect could last until the patient died, disease progression, or was lost to follow-up.

The limitations of this study included its retrospective nature, and the small number of patients studied. Nevertheless, the pain scores were recorded prospectively during the course of treatment and follow-up, thus avoiding recall bias. We also limited selection bias by including consecutive patients treated during the study period. The pain-relieving effect was nevertheless shown to be promising, and therefore a large-scale randomised study appears warranted.

\section{Conclusion}

In our experience, cementoplasty with or without RFA shows satisfactory, long-lasting pain control effects in oncological patients with bone metastases. The use of cementoplasty in painful bone metastases that are refractory to conventional treatments can be beneficial. However, the addition of RFA in treating vertebral metastases should be considered with caution, as it might give rise to neurological damage.

\section{References}

1. Brescia FJ. Pain management issues as part of the comprehensive care of the cancer patient. Semin Oncol 1993;20(2 Suppl 1):48-52.

2. Cleeland CS. The impact of pain on the patient with cancer. Cancer 1984;54(11 Suppl):2635-41. cross ref

3. Fallon $\mathrm{M}$, McConnell S. The principles of cancer pain management. Clin Med 2006;6:136-9. cross ref

4. Gangi A, Dietemann JL, Schultz A, Mortazavi R, Jeung MY, Roy C. Interventional radiologic procedures with CT guidance in cancer pain management. Radiographics
1996;16:1289-306.

5. Sabharwal T, Salter R, Adam A, Gangi A. Image-guided therapies in orthopedic oncology. Orthop Clin North Am 2006;37:105-12. cross ref

6. Gangi A, Guth S, Imbert JP, Marin H, Wong LS. Percutaneous bone tumour management. Semin Intervent Radiol 2002;19:279-86. cross ref

7. Deramond H, Depriester C, Galibert P, Le Gars D. Percutaneous vertebroplasty with polymethylmethacrylate. Technique, indications, and results. Radiol Clin North Am 
1998;36:533-46. cross ref

8. Saha S, Pal S. Mechanical properties of bone cement: a review. Biomed Mater Res 1984;18:435-62. cross ref

9. Weill A, Chiras J, Simon J, Rose M, Sola-Martinez T, Enkaoua E. Spinal metastases: indications for and results of percutaneous injection of acrylic surgical cement. Radiology 1996;199:241-7.

10. Marcy PY, Palussière J, Magne N, et al. Percutaneous cementoplasty for pelvic bone metastasis. Support Care Cancer 2000;8:500-3. cross ref

11. Posteraro AF, Dupuy DE, Mayo-Smith WW. Radiofrequency ablation of bony metastatic disease. Clin Radiol 2004;59:803-11. cross ref

12. Belfiore G, Tedeschi E, Ronza FM, et al. Radiofrequency ablation of bone metastases induces long-lasting palliation in patients with untreatable cancer. Singapore Med J 2008;49:565-70.

13. Nakatsuka A, Yamakado K, Maeda M, et al. Radiofrequency ablation combined with bone cement injection for the treatment of bone malignancies. J Vasc Interv Radiol 2004;15:707-12. cross ref

14. Toyota N, Naito A, Kakizawa $\mathrm{H}$, et al. Radiofrequency ablation therapy combined with cementoplasty for painful bone metastases: initial experience. Cardiovasc Intervent Radiol 2005;28:578-83. cross ref

15. van der Linden E, Kroft LJ, Dijkstra PD. Treatment of vertebral tumor with posterior wall defect using image-guided radiofrequency ablation combined with vertebroplasty: preliminary results in 12 patients. J Vasc Interv Radiol 2007;18:741-7. cross ref 